\title{
Potential neurological applications of Centella asiatica: a brief review
}

\author{
Abdul Gofir,,$^{*}$ Samekto Wibowo, ${ }^{1}$ Mohammad Hakimi ${ }^{2}$ \\ ${ }^{1}$ Department of Neurology, Faculty of Medicine, Public Health and Nursing, Universitas Gadjah \\ Mada, Yogyakarta, ${ }^{2}$ Department of Obstetrics and Gynecology, Faculty of Medicine, Public Health \\ and Nursing, Universitas Gadjah Mada, Yogyakarta, Indonesia
}

https://doi.org/10.22146/ijpther.1693

Submitted: $17 / 04 / 2021$

Accepted : 15/11/2021

\section{Keywords:}

Centella asiatica: neurological condition; stroke; epilepsy;

Alzheimer's disease; Parkinson's disease;

\section{ABSTRACT}

Centella asiatica (C. asiatica) or gotu kola has been used traditionally in many Asian countries as herbal medicines for many conditions, such as headache, asthma and memory enhancement. Centella asiatica has been also widely investigated for its neuroprotective effects in animal disease model including epilepsy, Alzheimer's and Parkinson's diseases. A brief review of neurological effects studies of $C$. asiatica in animal model was reported. Eligible studies published through December 2020 from PubMed and EMBASE journal data base were collected. Any keywords related to $C$. asiatica or gota kola AND neurological conditions were used. The results showed that several experimental studies concerning the neuroprotective properties of $C$. asiatica have been reported. Phytochemical studies reported that $C$. asiatica contained many bioactive compounds in which triterpenoids are the most identified. Furthermore, the triterpenoids have proven to have neuroprotective effect due to their effects of anti-inflammatory, antioxidant, improvement of mitochondrial dysfunctions, and increased brain-derived neurotrophic factors. Further studies are needed to investigate the neuroprotective mechanisms of $C$. asiatica. In conclusion, C. asiatica might have potential as an alternative medicine for neurological conditions, such as stroke, epilepsy, Alzheimer's and Parkinson's disease.

\begin{abstract}
ABSTRAK
Centella asiatica ( $C$. asiatica) telah digunakan secara tradisional di banyak negara di Asia sebagai obat herbal untuk berbagai kondisi, seperti nyeri kepala, asma, serta untuk memperkuat ingatan. Centella asiatica juga banyak dikaji efek neuroprotektifnya pada model hewan coba seperti penyakit epilepsy, Alzheimer dan Parkinson. Telaah secara singkat penelitian efek neuroprotektif $C$. asiatica pada hewan coba telah dilaporkan. Penelitian yang memenuhi kriteria yang dipublikasi hingga Desember 2020 dari data base jurnal PubMed dan EMBASE dikumpulkan. Kata kunci $C$. asiatica atau gota kola DAN neurological conditions digunakan. Hasil telaah menunjukkan penelitian eksperimental mengenai efek neuroprotektif telah dilaporkan. Penelitian fitokimia melaporkan $C$. asiatica mengandung banyak senyawa bioaktif dengan senyawa terpen sebagai senyawa terbanyak. Selanjutnya senyawa triterpenoid terbukti mempunyai efek neuroprotektif karena efeknya sebagai antiinflamasi, antioksidan, perbaikan disfungsi mitokondria dan peningkatan brain-derived neurotrophic factor (BDNF). Penelitian lanjut diperlukan untuk mengkaji mekanisme neuroprotektif C. asiatica. Dapat disimpulkan, C. asiatica mempunyai potensi sebagai obat alternative untuk gangguan saraf seperti stroke, epilepsy, Alzheimer dan Parkinson.
\end{abstract}




\section{INTRODUCTION}

Centella asiatica, also known as gotu kola or asiatic pennywort or pegagan in Indonesia, is belong to genus Cetella, Mackinlayoideae subfamily and Apiaceae family. Centella comprises approximately 53 species which is commonly grow in South East Asia regions, India, Japan, China, Taiwan and Korea. Centella asiatica is well known as medicinal plant which traditionally used to treat various conditions such as headache, body ache, asthma, memory enhancement and other illness. It also has been used for food as a vegetable salad, or in juices, in several Asian countries. ${ }^{1}$

Various active compounds have been isolated from $C$. asiatica. It contains triterpenoids centelloids such as madecassic acid, asiatic acid, madecassoside and asiaticoside. Centella asiatica also contains flavonoid derivatives such as quercetin and kaempferol. Other active found in $C$. asiatica are chlorogenic acid, polyacetylenes (e.g. cadinol, acetoxycentellinol, and asiaticin), vanillic acid, p-coumaric acid, o-coumaric acid, and transcinnamic acid, sterols (e.g. 11-oxoheneicosanil-cyclohexane, dotriacont-8- en-1-oic acid), phenolic acids (e.g. p-hydroxybenzoic acid), and polysaccharides (e.g. centellose), ${ }^{2,3}$

Preclinical studies reported that $C$. asiatica has several biological activities such as anti-inflammatory, antimicrobial, antifungal, antidepressant, antioxidant, anticancer effects. ${ }^{4}$ Centella asiatica has been well studied and documented as neuroprotective effects including epilepsy, Alzheimer's and Parkinson's diseases. In this brief review, we reported the neurological effects of $C$. asiatica in animal disease model.

\section{MATERIALS AND METHODS}

A systematic review concerning the neurological effects of $C$. asiatica in animal disease model was performed.
Eligible studies obtained from PubMed and EMBASE journal database published until December 2020 were gathered. Any keywords related to "Centella asiatica" (e.g.: "gotu kola") and neurological conditions (e.g.: stroke, epilepsy, neurodegenerative) were used for literature search. The results were then filtered only included studies in animal model. The process of selecting the studies was plotted in a flow diagram based on the Preferred Reporting Items for Systematic Reviews and MetaAnalyses (PRISMA) guidelines. ${ }^{5}$

\section{RESULT AND DISCUSSION}

\section{Possible mechanisms for neuroprotective properties of $C$. asiatica}

Sun et al. ${ }^{6}$ suggested four possible mechanisms ofactionforneuroprotection properties of $C$. asiatica, based on experimental studies of $C$. asiatica in Parkinson's disease (PD) and Alzheimer's disease (AD). Centella asiatica may exert its neuroprotective effects due to its anti-inflammatory effects, reduction of oxidative stress, improvement of mitochondrial dysfunctions, and increased brain-derived neurotrophic factors (BDNFs).

Neuroinflammation processes and inflammatory cytokines have been associated with neurodegenerative lesions. In Alzheimer's disease (AD), neuroinflammatory cytokines induce $\beta$-amyloid neurotoxicity through modulating amyloid precursor protein levels and metabolism. ${ }^{7}$ The pathology of $\mathrm{AD}$ is characterized by the accumulation of $\beta$-amyloid containing neuritic plaques and neurofibrillary tangles. ${ }^{8}$ Neuroinflammation is also the hallmark in the pathogenesis of PD.

Activation of glial cells and increases of pro-inflammatory cytokines has been reported in studies of PD. Activated astrocytes and microglia release pro-inflammatory cytokines that may be detrimental for neurons and exacerbate degeneration of $\mathrm{AD}$ 
neurons in substantia nigra pars compacta. $^{9}$ Neuroinflammation and neurodegenerative lesions lead to synaptic dysfunction and neuronal death in AD and PD. ${ }^{10}$ Cetella asiatica has been reported to significantly attenuate NO, TNF- $\alpha$, and free radicals in LPS-stimulated microglial cells. It is suggested that $C$. asiatica may exert its anti-inflammatory effects through inactivation of PI3K/AKT and ERK1/2 signaling pathway that in turn inhibits NF-kB activation. ${ }^{11}$

The brain has a high oxygen consumption but poor antioxidant system. Therefore, it is susceptible to oxidative stress, especially the hippocampus and cortical regions. Problems in cholinergic channeling in the cortical areas and regions of hippocampal have been associated with cognitive disorders. Increased AChE activity is associated with increased acetylcholine breakdown, which in turn leads to cholinergic dysfunction that manifests as cognitive deficits. It is postulated that, $C$. asiatica exerts its neuroprotective properties by modifying superoxide dismutase (SOD), reduced glutathione (GSH) and protein carbonyl (PC) activities, as well as lowering the AChE activity which improves cholinergic transmission. ${ }^{12}$

Shinomol et al. ${ }^{13}$ evaluated the activity of $C$. asiatica in ameliorate the neuronal oxidative distress in rodents of prepubertal age. Male mice were fed with a $C$. asiatica diet (with a dose of 0.5 and 1\%) for 4 weeks, and oxidative stress in brain regions were measured. The mice fed $C$. asiatica showed significant reduction of malondialdehyde (3-50\%), reactive oxygen species/ROS (32-42\%) and hydroperoxide (30-35\%) levels, which was accompanied by increased antioxidant enzyme activities in all brain regions. Furthermore, the aqueous extract of $C$. asiatica showed significant free radical scavenging activity and ameliorated the 3-NPA induced oxidative stress response in brain mitochondria under in vitro exposure. Taken together, these data suggest that $C$. asiatica has the propensity to ameliorate oxidative impairments in the brain and it may have neuroprotective properties in response to oxidative stress.

Antioxidant properties of $C$. asiatica may due its effect on glutathione level. Glutathione is an antioxidant and found as reduced forms intracellularly. Glutathione is a free radical scavenger and reacts with a wide variety of free radicals. LowerGSHleveland glutathioneS-transferase has been associated with the increase of free radical levels and weaker glutathione systems in face of oxidative stress. Administration of $C$. asiatica may restore GSH level that in turn increase glutathione-S-transferase activity. ${ }^{14}$ A study found that treatment with $C$. asiatica was associated with increased glutathione level compared with controls in rats of an AD model. ${ }^{15}$

Another in vitro and in vivo study were performed to assess the effect of ethanolic extract of $C$. asiatica. SH-SY5Y cells treated with cent $C$. asiatica showed significant reduction in the AChE activity in a dose-dependent manner. A similar result was also found in an experimental study of neuroinflammation with Sprague Dawley rats' model. ${ }^{16}$

Centella asiatica may also modify mitochondrial function. Mitochondria are organelles that perform aerobic respiration to generate energy for cellular functions. Mitochondrial dysfunction has been associated with the development of neurodegenerative diseases. Previous studies reported that mitochondrial dysfunction is a trigger or propagator of neurodegenerative processes. Therefore, it can be postulated that treatments that target mitochondrial dysfunction may prevent $C$. asiatica may modify mitochondrial activity, increase the expression of mitochondrial enzymes and increase its content. These results suggested the possibility of $C$. asiatica having beneficial effects on mitochondrial activity. It is noteworthy that $C$. asiatica also had beneficial effects on mitochondrial function in the absence of $A \beta$, suggesting broader potential application of $C$. asiatica outside $\mathrm{AD}$ and PD. ${ }^{17}$ 
BDNF plays important roles in neuron maintenance, survival, and neurotransmitter regulation. BDNF promotes synaptic growth and is involved in learning and memory processes. Its level is reduced in the brain of neurodegenerative disease patients. It is suggested that abnormal BDNF levels may be the result of chronic inflammation in the brain. ${ }^{18}$ Centella asiatica increased the BDNF concentration in the hippocampal region. Centella asiatica treatment may up-regulate BDNF protein and mRNA expression. ${ }^{19}$

Jiang et $a l .{ }^{20}$ speculated that asiatic acid and madecassic acid had significant effect of induction on both neurofilament expression of NF68 and NF200 neurite outgrowth. NF68 is a representative marker for the early stage of differentiation neurons, while NF200 is a marker for neuron differentiation of the latter stage. They also suggested that the combination of asiatic acid and madecassic acid induces neuronal differentiation partially through mediating the MEK signaling pathways.

\section{Experimental models neuroprotective effects}

\section{Cognitive impairment}

Rao et al. ${ }^{21}$ investigated the nootropic effect of $C$. asiatica in mice. Administration of $C$. asiatica for fifteen days in 3-months old mice was associated with better learning and memory performance. Results from the radial arm maze test showed an increased number of correct entries in a dose-dependent manner. They also treated another group of newborn mice with $C$. asiatica for 15 days [from day 15 to day 30 postpartum (p.p.)] and were compared with a control group after 1 and 6 months p.p. The treatment group had significantly better results in hole board tests and radial arm maze, but not in locomotor activity. Administration of $C$. asiatica was also associated with increased hippocampal acetylcholine esterase activity. Histologic studies found increased arborization of hippocampal CA3 neurons at one month and 6 months time points. Taken together, these results suggested that $C$. asiatica treatment during the postnatal developmental stage may affect the neuronal morphology and promote higher brain function.

Another study reported that $C$. asiatica extract improved age-related cognitive impairment in mice. In the study, 20 month-old CB6F1 mice were treated with $C$. asiatica extract $(2 \mathrm{mg} /$ $\mathrm{mL}$ ) for 2 weeks before behavioral testing. The authors found better performance in memory and executive function. Histology examination revealed increased synaptic density in the hippocampus, increased expression of NRF2 and porin as antioxidant and mitochondrial markers, respectively. ${ }^{22}$

Thong-asa et al. ${ }^{23}$ studied cognition and its relation to the effect of $C$. asiatica. They studied hippocampal pathology as a model of dementia in mild chronic cerebral hypoperfusion $(\mathrm{CCH}) . \mathrm{CCH}$ was induced by permanent right common carotid artery occlusion (RCO). Cetella asiatica ameliorate learning ability deficit in 2 and 12 months after $\mathrm{CCH}$. They also found that $C$. asiatica ameliorated damages in neuron of the dorsal hippocampus at 2 months after $\mathrm{CCH}$ if treatment started 24 hours post$\mathrm{CCH}$. After 12 months, improvement in memory and learning were reported, as well as reduction in dentate gyrus neuronal damage.

Firdaus et al. ${ }^{12}$ analyzed the neuroprotectiveeffectofC.asiaticaagainst the D-gal-stimulated aging rat model. They found that $C$. asiatica improved behavioral and cognitive functions, and prevented neurodegeneration in these animal subjects. Centella asiatica supplementation may counter behavioral deficits through several possible mechanisms, either by improving spatial memory, reducing anxiety, or improvement in coping behavior and locomotor activity. 


\section{Epilepsy}

Epilepsy is a common burden on chronic neurological disorder. It is characterized by unprovoked and spontaneous seizures. A study used pentylenetetrazol (PTZ) in rats to cause epileptic seizures, as well as increase ACh and inhibit AChE in all brain regions. They reported anticonvulsant effects of C. asiatica against PTZ-induced seizures. Increased acetylcholine content and reduced acetylcholinesterase activity were recorded in a number of brain regions during PTZ-induced seizures. Meanwhile, animals pretreated with $C$. asiatica extracts had higher acetylcholine and acetylcholinesterase levels. These findings suggested that $C$. asiatica may have beneficial effects in the cholinergic system that explained its anticonvulsant. ${ }^{24}$

\section{Stroke}

A study conducted by Lee et al. ${ }^{25}$ using multiple stroke models in rats suggested that asiatic acid caused significant reduction in infarct volume and improved neurological outcome. Similar results were still found even when $C$. asiatica was administered up to 12 hours after ischemia onset. The treatment was reported effective against multiple focal ischemia models. It was also suggested that treatment with $C$. asiatica had a long therapeutic time window. The beneficial effects of asiatic acid in post-ischemic lesion may be mediated through its protective effects on mitochondria and inhibition of matrix metalloproteinase-9 induction and activation.

Tabassum et al. ${ }^{26}$ investiagted the effects of $C$. asiatica on ischemic stroke. They used Wistar rats treated with transient focal middle cerebral artery occlusion (MCAO). Before occlusion, these rats were pretreated with $C$. asiatica extract for 21 days. The animals were then subjected to right MCAO for 2 hours, followed by 22 hours of reperfusion. Rats pretreated with $C$. asiatica had better neurobehavioral activity and reduced infarction volume as well as better histological brain morphology, compared to control animals. Furthermore, supplementation with $C$. asiatica in the $M C A O$ group was associated with lower thiobarbituric acid reactive species, higher glutathione content and antioxidant enzymes in a dose-dependent manner.

\section{Alzheimer's and Parkinson's disease}

The $\mathrm{AD}$ and PD are the two most common neurodegenerative disease, characterized by cognitive and motoric function degeneration due to loss of neuronal cells. Asiatic acid, a triterpenoid component of $C$. asiatica, may have potential for treatment of AD. Asiatic acid may have protective effects against various pathological features of $\mathrm{AD}$. A study of $\mathrm{AD}$ model, using aluminum chloride $\left(\mathrm{AlCl}_{3}\right)$ induced amyloid pathology, found that $\mathrm{AlCl}_{3}$ treatment for 6 weeks was associated with significant reduction in spatial memory performance, anxiety, and motor dysfunction, as well as reduced expression of cyclin-dependent kinase 5 (a marker of tau proteins phosphorylation), pTau, oxidative stress, and apoptosis. Pretreatment with asiatic acid for 7 weeks resulted in attenuated $\mathrm{AlCl}_{3}$-induced cognitive impairment, $\mathrm{A} \beta$ burden, oxidative stress, cholinergic deficits, Tau pathology, inflammation, and apoptosis in these rats. It is suggested that asiatic acid ameliorated AlCl3-induced pathological alterations in hippocampus and cortex regions. ${ }^{27}$

A study of the AD model in rats using intracerebroventricular injection of streptozotocin reported that $C$. asiatica was effective to prevent cognitive deficits in rats. Pretreatment with aqueous extract of $C$. asiatica resulted in improved cognitive behavior in a dosedependent manner. ${ }^{15}$

Centella asiatica may exert its neuroprotective properties through a number of possible mechanisms. Studies suggested that $C$. asiatica has anti-inflammatory effects, ameliorates oxidative stress, improves mitochondrial 
dysfunctions, and increases brainderived neurotrophic factors. Results from experimental studies should be interpreted cautiously and cannot be extrapolated directly for clinical routines. Therefore, human studies should be performed to confirm the findings of these phytochemical experimental studies.

\section{CONCLUSION}

Evidence from experimental animal studies suggest the potential of $C$. asiatica as alternative treatment for neurological conditions, such as stroke, epilepsy, Alzheimer's and Parkinson's disease.

\section{ACKNOWLEDGEMENTS}

The authors would like to thank Ismail Setyopranoto, MD, PhD, Head of Department of Neurology, Faculty of Medicine, Public Health and Nursing, Universitas Gadjah Mada, Yogyakarta, Indonesia.

\section{REFERENCES}

1. Plengmuankhae W, Tantitadapitak C. Low temperature and water dehydration increase the levels of asiaticoside and madecassoside in Centella asiatica (L.) Urban. S Afr J Bot 2015; 97:196-203.

https://doi.org/10.1016/jsajb.2015.01.013

2. Gray NE, Alcazar Magana A, Lak P, Wright KM, Quinn J, Stevens JF, et al. Centella asiatica: phytochemistry and mechanisms of neuroprotection and cognitive enhancement. Phytochem Rev 2018; 17:161-94. https://doi.org/10.1007/s11101-017-9528-y

3. Orhan IE. Centella asiatica (L.) Urban: from traditional medicine to modern medicine with neuroprotective potential. Evid Based Complement. Alternat Med 2012; 2012:946259. https://doi.org/10.1155/2012/946259

4. Zheng CJ, Qin LP. Chemical components of Centella asiatica and their bioactivities. J Chin Integr Med
2007; 5(3):348-51.

https://doi.org/10.3736/jcim20070324

5. Higgins JPT. Cochrane Collaboration

(Eds.). Cochrane Handbook for Systematic Reviews of Interventions, Second ed. Cochrane book series. Hoboken, NJ, Wiley-Blackwell, 2020.

6. Sun B, Wu L, Wu Y, Zhang C, Qin $\mathrm{L}$, Hayashi $\mathrm{M}$, et al. Therapeutic potential of Centella asiatica and its triterpenes: a review. Front Pharmacol 2020; 11:568032.

https://doi.org/10.3389/fphar.2020.568032

7. Alasmari F, Alshammari MA, Alasmari AF, Alanazi WA, Alhazzani K. Neuroinflammatory cytokines induce amyloid beta neurotoxicity through modulating amyloid precursor protein levels/metabolism. Biomed Res Int 2018: 2018:3087475 https://doi.org/10.1155/2018/3087475

8. Zhao Y, Zhang Y, Zhang J, Zhang X, Yang G. Molecular mechanism of autophagy: its role in the therapy of Alzheimer's disease. Curr Neuropharmacol 2020; 18(8):720-39. https://doi.org/10.2174/157015 9X18666200114163636

9. Wang Q, Liu Y, Zhou J. Neuroinflammation in Parkinson's disease and its potential as therapeutic target. Transl Neurodegener 2015; 4:19.

https://doi.org/10.1186/s40035-015-0042-0

10. Martínez-Cué C, Rueda N. Cellular senescence in neurodegenerative diseases. Front Cell Neurosci 2020; 14:16.

https://doi.org/10.3389/fncel.2020.00016

11. Mairuae N, Cheepsunthorn P, Buranrat B. Anti-inflammatory and anti-oxidative effects of Centella asiatica extract in lipopolysaccharidestimulated BV2 microglial cells. Pharmacogn Mag 2019; 15(60):140-6. https://doi.org/10.4103/pm.pm_197_18

12. Firdaus Z, Singh N, Prajapati SK, Krishnamurthy S, Singh TD. Centella asiatica prevents D-galactoseInduced cognitive deficits, oxidative stress and neurodegeneration in the adult rat brain. Drug Chem Toxicol 
2020: 1-10.

https://doi.org/10.1080/01480545.202 0.1833907

13. Shinomol GK, Muralidhara. Effect of Centella asiatica leaf powder on oxidative markers in brain regions of prepubertal mice in vivo and its in vitro efficacy to ameliorate 3-NPA-induced oxidative stress in mitochondria. Phytomedicine 2008; 15(11):971-84.

h t tps://doi.org/10.1016/j. phymed.2008.04.010

14. Kumar A, Dogra S, Prakash A. Neuroprotective effects of Centella asiatica against intracerebroventricular colchicineinduced cognitive impairment and oxidative stress. Int J Alzheimers Dis 2009; 2009:972178.

https://doi.org/10.4061/2009/972178

15. Veerendra Kumar MH, Gupta Y. Effect of Centella asiatica on cognition and oxidative stress in an intracerebroventricular streptozotocin model of Alzheimer's disease in rats. Clin Exp Pharmacol Physiol 2003; 30(5-6):336-42.

https://doi.org/10.1046/j.14401681.2003.03842.x

16. Hafiz ZZ, Amin MAM, James RMJ, Teh LK, Salleh MZ, Adenan MI. Inhibitory effects of raw-extract Centella asiatica (RECA) on acetylcholinesterase, inflammations, and oxidative stress activities via in vitro and in vivo. Molecules 2020; 25(4):892.

h t t p s://d o i.org/10.3390/ molecules25040892

17. Gray NE, Zweig JA, Matthews DG, Caruso M, Quinn JF, Soumyanath A. Centella asiatica attenuates mitochondrial dysfunction and oxidative stress in a $\beta$-exposed hippocampal neurons. Oxid Med Cell Longev 2017; 2017:7023091. https://doi.org/10.1155/2017/7023091

18. Lima Giacobbo B, Doorduin J, Klein HC, Dierckx RAJO, Bromberg E, de Vries EFJ. Brain-derived neurotrophic factor in brain disorders: focus on neuroinflammation. Mol Neurobiol 2019; 56(5):3295-312. https://doi.org/10.1007/s12035-018-1283-6

19. Sari DCR, Arfian N, Tranggono U, Setyaningsih WA, Romi MM, Noriaki E. Centella asiatica (Gotu kola) ethanol extract up-regulates hippocampal brain-derived neurotrophic factor (BDNF), tyrosine kinase B (TrkB) and extracellular signal-regulated protein kinase 1/2 (ERK1/2) signaling in chronic electrical stress model in rats. Iran J Basic Med Sci 2019; 22(10):1218-24.

h t t p s://d oi.org/10.22038/ ijbms.2019.29012.7002

20. Jiang $H$, Zheng G, Lv J, Chen H, Lin J, Li Y, et al. Identification of Centella asiatica's effective ingredients for inducing the neuronal differentiation. Evid Based Complement. Alternat Med 2016; 2016:9634750. https://doi.org/10.1155/2016/9634750

21. Rao S, Chetana M, Umadevi P. Centella asiatica treatment during postnatal period enhances learning and memory in mice. Physiol Behav 2005; 86(4):449-57.

h t tp s://doi.org/10.1016/j . physbeh.2005.07.019

22. Gray NE, Zweig JA, Caruso M, Martin MD, Zhu JY, Quinn JF, et al. Centella asiatica increases hippocampal synaptic density and improves memory and executive function in aged mice. Brain Behav 2018; 8(7):e01024.

https://doi.org/10.1002/brb3.1024

23. Thong-Asa W, Tilokskulchai K, Chompoopong S, Tantisira $\mathrm{MH}$. Effect of Centella asiatica on pathophysiology of mild chronic cerebral hypoperfusion in rats. Avicenna J Phytomed 2018; 8(3):210-26.

24. Visweswari G, Prasad KS, Chetan PS, Lokanatha V, Rajendra W. Evaluation of the anticonvulsant effect of Centella asiatica (gotu kola) in pentylenetetrazol-induced seizures with respect to cholinergic neurotransmission. Epilepsy Behav 2010; 17(3):332-5.

h t t p s://doi.org/10.1016/j . yebeh.2010.01.002 
25. 25. Lee KY, Bae ON, Serfozo K, Hejabian S, Moussa A, Reeves M, et al. Asiatic acid attenuates infarct volume, mitochondrial dysfunction, and matrix metalloproteinase-9 induction after focal cerebral ischemia. Stroke 2012; 43(6):1632-8. h t t p s : // d o i.org/10.1161/ STROKEAHA.111.639427

26. Tabassum R, Vaibhav K, Shrivastava $\mathrm{P}$, Khan A, Ahmed ME, Javed $\mathrm{H}$, et al. Centella asiatica attenuates the neurobehavioral, neurochemical and histological changes in transient focal middle cerebral artery occlusion rats. Neurol Sci 2013; 34(6):925-33. https://doi.org/10.1007/s10072-012-1163-1 27. Rather MA, Thenmozhi AJ, Manivasagam T, Saravanababu C, Guillemin GJ, Essa MM. Asiatic acid attenuated aluminum chlorideinduced Tau pathology, oxidative stress and apoptosis via AKT/GSK$3 \beta$ signaling pathway in Wistar rats. Neurotox Res 2019; 35(4):955-68. https://doi.org/10.1007/s12640-019-9999-2 